\title{
NEKARA: PENINGGALAN SENI BUDAYA DARI ZAMAN PERUNGGU
}

\author{
Hanny Wijaya \\ Jurusan Desain Komunikasi Visual, Fakultas Komunikasi dan Multimedia, Universitas Bina Nusantara \\ Jl. K.H. Syahdan No. 9, Kemanggisan, Palmerah, Jakarta Barat 11480 \\ hwijaya@binus.edu
}

\begin{abstract}
Cultural development nowadays could not be separated with the cultural development from the past. Dong Son culture, which was developed in Vietnam area, had given a big influence to cultural development in Asian regions during the Bronze Age. One of the great heritages from Dong Son culture was a Dong Son drum or was known as Nekara in Indonesian region. Nekara which forms like a drum has many functions that based on culture and tradition from each area. The main function of Nekara was generally as a music instrument for festivals or cultural events, such as prayers for rain, good harvest, funeral, wedding ceremony, etc. Moreover, in some specific regions, nekara had also been used as a mausoleum to keep the corpse or dead body for funeral, it was also had a function as a symbol of power for tribe leaders. The motifs on drums or nekara also had a symbolic meaning or a specific representation based on its function.Article presents the knowledge on the background and function of nekara more specific and readers will know more details about Dong Son culture and its unique heritage, i.e. Nekara.
\end{abstract}

Keywords: nekara, Dong Son culture, bronze age

\begin{abstract}
ABSTRAK
Perkembangan kebudayaan saat ini tidak terlepas dari perkembangan kebudayaan yang ada pada masa lalu. Kebudayaan Dong Son yang berkembang di wilayah Vietnam telah memberi pengaruh besar pada perkembangan kebudayaan di wilayah Asia pada zaman Perunggu. Salah satu peninggalan perunggu dari kebudayaan Dong Son adalah peninggalan berupa Dong Son drum atau dikenal dengan istilah Nekara di wilayah Indonesia. Nekara yang berbentuk seperti drum memiliki berbagai fungsi yang disesuaikan dengan adat dan tradisi dari masing-masing wilayah. Beberapa fungsi utama dari nekara antara lain adalah sebagai alat musik yang digunakan pada upacara pemanggil hujan, upacara pernikahan, upacara pemakaman, dsb. Selain itu, di beberapa wilayah tertentu, nekara juga digunakan sebagai peti untuk menyimpan jenazah atau mausoleum dan juga berfungsi sebagai simbol kekuatan bagi pemimpin atau kepala suku. Motif yang digambarkan pada nekara juga memiliki arti simbolik atau representasi khusus sesuai dengan fungsi dari nekara tersebut. Artikel menjelaskan latar belakang dan fungsi yang lebih spesifik dari nekara sehingga pembaca dapat mengetahui lebih detail mengenai kebudayaan Dong Son dan peninggalannya yang khas, yaitu Nekara.
\end{abstract}

Kata kunci: nekara, budaya Dong Son, zaman perunggu 


\section{PENDAHULUAN}

Perkembangan seni kebudayaan di Indonesia sudah berlangsung sejak zaman pra-sejarah. Seiring dengan perkembangan peradaban dan pengetahuan manusia, maka metode penciptaan suatu objek mulanya berdasarkan pada kebutuhan manusia secara fungsional. Berdasarkan periodisasi perkembangan peradabannya, manusia melalui era Paleolitikum (Batu Tua), kemudian era Mesolitikum (Batu Tengah), era Neolitikum (Batu Baru), dan memasuki era akhir zaman batu, yaitu Megalitikum (Batu Besar). Setelah melewati zaman batu, peradaban manusia sudah berkembang dengan cukup pesat dan memasuki era baru yaitu Zaman Perunggu (Bronze Age), di mana perkembangan peradaban diperlihatkan dengan kemampuan manusia untuk mengolah logam perunggu menjadi berbagai produk yang digunakan untuk kehidupan mereka, baik secara fungsional maupun secara spiritual.

Berbagai perkembangan tersebut juga tidak luput dari pengaruh budaya asing yang saling memengaruhi dan berakulturasi dengan budaya lokal yang ada di Indonesia. Salah satu kebudayaan yang memberi pengaruh besar pada karya peninggalan manusia Indonesia pada zaman Perunggu (Bronze Age) adalah kebudayaan dari bangsa Vietnam yang dikenal dengan kebudayaan Dong Son. Sesungguhnya kebudayaan Dong Son sendiri sudah masuk dan memberi pengaruh awal sejak era Mesolitikum hingga era Megalitikum, namun pengaruhnya yang sangat besar dirasakan pada zaman Perunggu.

Salah satu pengaruh budaya Dong Son yang memberi pengaruh besar bagi kebudayaan Indonesia maupun beberapa negara Asia Tenggara lainnya adalah metode pengolahan perunggu. Berbagai peninggalan karya seni budaya dari era Bronze Age ini antara lain patung, bejana, perhiasan, dan peninggalan berupa Nekara. Berikut akan kita bahas lebih lanjut secara khusus mengenai peninggalan Nekara ini, dari mulai latar belakang, fungsi, hingga pengaruhnya bagi masyarakat Indonesia pada era tersebut.

Artikel bertujuan mengetahui dan mempelajari lebih dalam mengenai budaya dan kehidupan masyarakat Indonesia pada zaman pra-sejarah, khususnya pada Zaman Perunggu. Dengan mengetahui latar belakang dan perkembangan budaya masyarakat tersebut, maka hal tersebut tentunya akan memberi gambaran yang jelas mengenai kehidupan masyarakat pada saat itu, bagaimana pengaruh kebudayaan Dong Son masuk dan berkembang, dan lebih memahami sistem kepercayaan masyarakat pada saat itu. Seperti yang sudah kita ketahui, manusia pada era tersebut masih menganut Animisme dan Dinamisme. Pengetahuan ini diharapkan dapat membuka wawasan bagi kita, dan dapat dipahami oleh kita masing-masing demi menjaga kelestarian peninggalan seni budaya Indonesia.

\section{METODE PENELITIAN}

Artikel disusun menggunakan pendekatan studi literatur dan studi data dari jaringan elektronik yang dijadikan sumber informasi utama dari penelitian ini. Selain itu, penulis juga melakukan riset di lapangan dengan mengunjungi Museum Nasional yang memiliki beberapa koleksi peninggalan Nekara dari beberapa wilayah di Indonesia. Setelah itu, penulis mengembangkan data-data dan informasi yang ada dari sumber tersebut dengan menambahkan informasi lanjut yang berdasarkan pada pengamatan, hipotesis, dan pengembangan ide dari materi yang ada. 


\section{HASIL DAN PEMBAHASAN}

Seperti yang sudah disinggung sebelumnya, kebudayaan Indonesia pada zaman perunggu mendapat banyak pengaruh dari kebudayaan Dong Son yang berasal dari Vietnam. Peninggalan berupa Nekara merupakan salah satu peninggalan yang penting bagi masyarakat Indonesia pada zaman Perunggu juga banyak mendapat pengaruh besar dari kebudayaan Dong Son tersebut. Oleh karena itu, sebelum kita membahas lebih detail mengenai Nekara, ada baiknya kita memahami terlebih dahulu mengenai perkembangan seni budaya di Vietnam dan kebudayaan Dong Son tersebut.

\section{Seni Vietnam}

Perkembangan seni bangsa Vietnam memiliki sejarah yang cukup panjang dan kompleks, beberapa contoh karya seninya ditelusuri dan ditemukan berasal dari zaman batu sekitar 8,000 tahun sebelum Masehi. Seperti yang sudah kita ketahui, bangsa Cina mendominasi bangsa Vietnam selama ribuan tahun, dimulai sejak abad ke-dua sebelum Masehi. Oleh karena itu, tidak dapat dipungkiri bahwa seni budaya bangsa Vietnam banyak mendapat pengaruh dari budaya Cina. Akan tetapi, seni Vietnam selalu memiliki ciri khusus yang menjadi karakter khusus dan membedakannya dari seni di Cina. Baru setelah abad ke-19 seni Vietnam beralih menjadi seni modern ketika bangsa Perancis masuk dan mengambil alih Vietnam. Salah satu kebudayaan penting yang memberi pengaruh besar pada seni Vietnam adalah kebudayaan Dong Son.

\section{Kebudayaan Dong Son}

Berdasarkan periodisasi sejarahnya, seni Vietnam mengalami banyak perkembangan sejak zaman pra-sejarah hingga zaman modern. Namun satu kebudayaan yang memberi pengaruh besar tidak hanya bagi bangsa Vietnam sendiri, tetapi juga bagi beberapa negara di Asia Tenggara, yaitu kebudayaan Dong Son.

Kebudayaan Dong Son merupakan kebudayaan yang berkembang pada zaman Perunggu (Bronze Age) di Vietnam yang berpusat di wilayah lembah sungai Merah (Song Hong) di wilayah utara negara Vietnam. Pada era ini, kerajaan awal bangsa Vietnam, yaitu kerajaan Van Lang dan Au Lac muncul. Kerajaan ini memberi pengaruh besar di berbagai wilayah Asia Tenggara, termasuk wilayah kepulauan Nusantara sekitar tahun 1000 SM hingga tahun 1 SM.

Masyarakat Dong Son, yang juga dikenal dengan sebutan Lac atau Lac Viet, adalah masyarakat petani dan peternak yang andal. Mereka terampil menanam padi, memelihara kerbau dan babi. Mereka juga memancing dan berlayar dengan menggunakan perahu kano panjang. Mereka juga memiliki kemampuan untuk mengolah logam perunggu dengan baik. Hal ini dapat dibuktikan oleh banyaknya peninggalan berupa gendang (Dong Son Drums), yang juga dapat ditemukan di berbagai wilayah Asia Tenggara dan Cina Selatan.

Kebudayaan Dong Son terkait erat dengan kebudayaan Tibeto-Burman, kebudayaan Dai di daerah Yunnan dan Laos, kebudayaan Mon-Khmer dan kebudayaan tersebut juga berhubungan dengan wilayah arkeologis di wilayah Laos yang disebut The Plain of Jars. Beberapa artefak yang hampir mirip juga ditemukan di wilayah Kamboja sekitar sungai Mekong yang diperkirakan dari 4,000 tahun SM. Pengaruh kebudayaan Dong Son juga dapat dilihat di beberapa wilayah Asia Tenggara, mulai dari Moko drum di Indonesia (diperkirakan bentuknya diadaptasi dari Dong Son drum), hingga pengaruhnya pada peninggalan lainnya berupa keris. 


\section{Latar Belakang}

Diperkirakan, asal mula kebudayaan Dong Son berasal dari teknik pengolahan logam pada zaman Perunggu kuno. Teori tersebut berdasarkan pada asumsi peneliti bahwa teknik pengolahan perunggu sebenarnya berasal dari wilayah timur Asia, di Cina bagian utara. Akan tetapi, ide tersebut dibantah dengan adanya penemuan arkeologis di wilayah timur laut Thailand pada tahun 1970-an. Penemuan ini membuktikan bahwa ternyata pengolahan logam perunggu bermula di wilayah Asia Tenggara terlebih dahulu, baru kemudian diikuti oleh Cina, bukan kebalikannya.

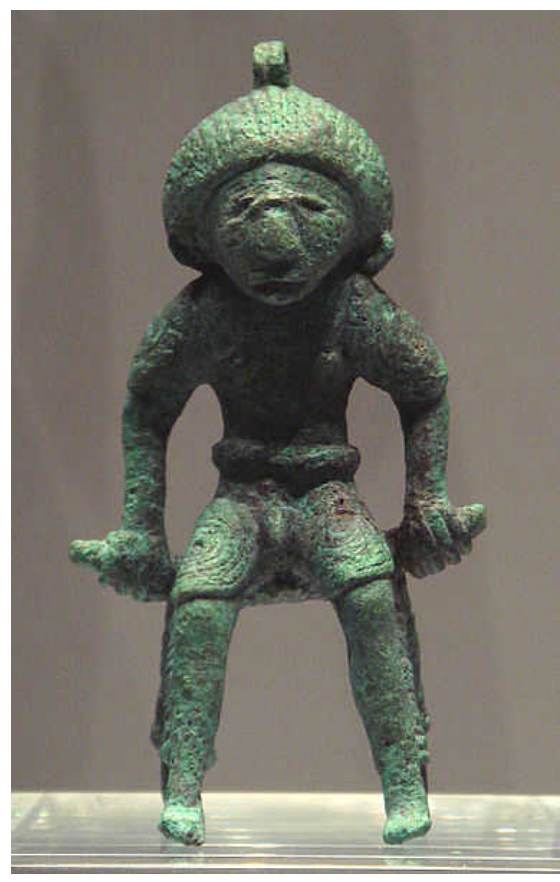

Gambar 1 Patung Perunggu, Kebudayaan Dong Son, 500 SM-300 SM, Thailand

Kebudayaan Dong Son dan beberapa kebudayaan lainnya di Asia Tenggara dikenal dengan teknik pengolahan perunggu yang disebut dengan lost-wax atau disebut juga teknik cire perdue yang telah dikenal sejak awal, sekitar 1000 tahun sebelum Masehi. Pernyataan mengenai asal mula teknik pengolahan perunggu ini didukung oleh para arkeolog Vietnam modern.

\section{Metode lost-wax atau cire perdue}

Teknik pengolahan logam, yang disebut dengan metode lost-wax atau lebih dikenal dengan istilah cire perdue yang berasal dari bahasa Prancis (bahasa latin: cera perduta), merupakan proses pembuatan patung dari material logam (misalnya perak, emas, perunggu). Teknik pengolahan logam ini telah digunakan sejak zaman logam dan metode ini terus dikembangkan hingga saat ini (era modern).

Metode cire perdue ini dilakukan dengan melewati beberapa tahapan penting. Awalnya, benda yang dikehendaki harus dibuat dulu dari lilin, lengkap dengan bagian detailnya. Lilin tersebut kemudian dibungkus dengan tanah liat (clay) dan selanjutnya dipanaskan sehingga lilin menjadi cair. Selanjutnya, logam cair dituangkan ke dalam tanah liat yang telah terbentuk; dan setelah dingin, tanah dipecahkan. Sehingga akhirnya terbentuklah benda yang dikehendaki. Untuk lebih jelasnya, perhatikan Gambar 2. 


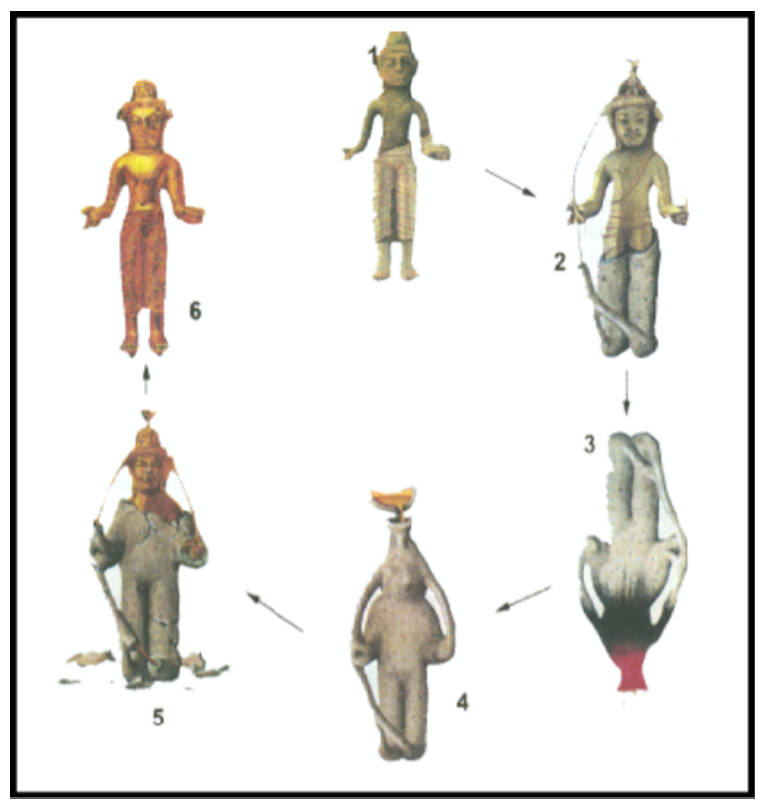

Gambar 2 Tahapan proses cire perdue

\section{Kesenian Dong Son}

Kebudayaan Dong Son menghasilkan banyak karya seni yang beraneka ragam karena masyarakatnya mendapat berbagai macam pengaruh dan aliran budaya. Hal ini tampak pada bendabenda artefak kehidupan sehari-hari maupun peralatan lainnya yang bersifat ritual keagamaan yang rumit. Umumnya, material yang digunakan adalah logam perunggu. Sebagai contoh, benda-benda seperti kapak dengan selongsong, ujung tombak, pisau belati, mata bajak, penyangga berkaki tiga dengan bentuk yang rumit dan dekoratif. Selain itu, berbagai peralatan rumah tangga seperti gerabah, bejana, dan berbagai aksesoris seperti perhiasan-perhiasan termasuk gelang yang terbuat dari kerang, manik-manik dari kaca, dan lain-lainnya dihias dengan berbagai dekorasi yang berbentuk geometris, misalnya jalinan arsir, segitiga dan bentuk spiral. Namun karya peninggalan besar yang menjadi ciri khas kebudayaan Dong Son adalah peninggalan berupa Dong Son drum yang tersebar di berbagai wilayah Asia, termasuk Indonesia.

\section{Dong Son drums atau Nekara}

Dong Son drum atau disebut juga Heger Type I drums, atau juga disebut sebagai Nekara dalam bahasa Indonesia, merupakan gendang atau drum yang terbuat dari perunggu dan merupakan salah satu peninggalan penting dari kebudayaan Dong Son. Benda ini diperkirakan diciptakan sekitar 600 tahun sebelum Masehi hingga abad ke-3 sesudah Masehi; berbentuk seperti dandang berpinggang pada bagian tengahnya dengan selaput suara berupa logam atau perunggu. Nekara merupakan salah satu bukti karya terbaik dari pengolahan logam pada kebudayaan Dong Son.

Seperti yang sempat disinggung sebelumnya, kebudayaan Dong Son erat kaitannya dengan teknik pengolahan perunggu, yaitu metode lost-wax atau cire perdue. Pembuatan Nekara juga dibuat dengan teknik tersebut. Dengan wujud fisik setinggi kurang lebih satu meter dan berat lebih dari 1000 kilogram, nekara terbukti merupakan salah satu benda peninggalan zaman perunggu yang menunjukkan majunya peradaban bangsa tersebut pada zamannya. Berikut adalah contoh gambar nekara. 


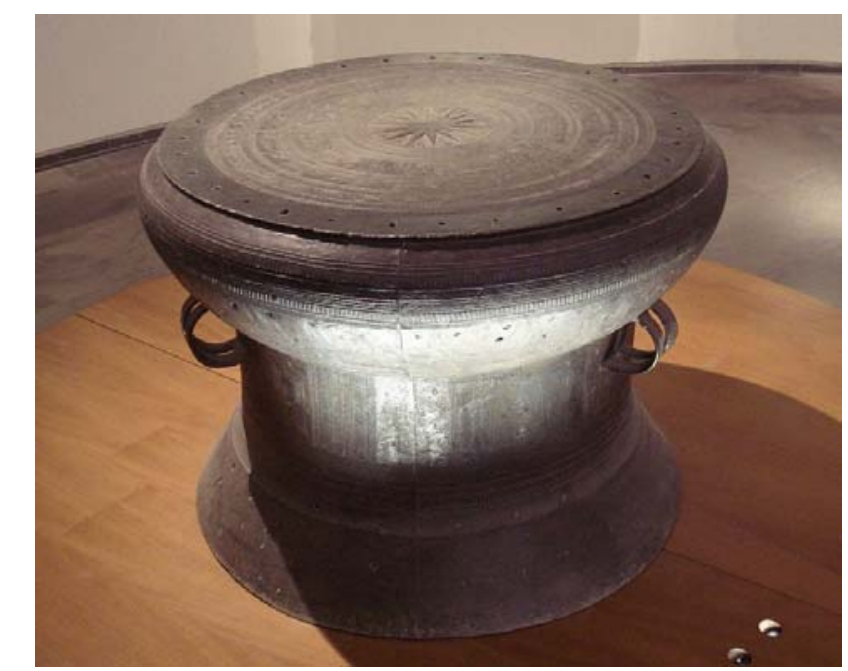

Gambar 3 Drum dari Song Da, Vietnam Kebudayaan Dong Son, pertengahan 1000 SM, Perunggu

Berdasarkan hasil penelitian yang dilakukan oleh para arkeolog, mereka menemukan bahwa nekara awal terkait erat dengan penampilan struktur dasar dari desain dekoratif keramik pada kebudayaan Phung Nguyen. Walaupun masih belum dapat dipastikan apakah fungsi sebenarnya dari nekara tersebut bagi masyarakatnya, namun ada beberapa pendapat mengenai tujuan dibuatnya nekara ini. Beberapa pendapat yang ada antara lain, diperkirakan benda ini dibuat untuk tujuan upacara keagamaan, digunakan untuk berpawai mengantar para pria ke medan perang, atau untuk penggunaan pada berbagai aktivitas lainnya dengan tujuan yang hampir mirip. Ada juga teori lainnya yang menyatakan bahwa kegunaan dari nekara tersebut kemungkinan adalah sebagai kalender musiman bagi masyarakat lokal, dikarenakan adanya tanda panah yang diukir pada benda tersebut.

Namun hasil penelitian menemukan bahwa nekara rupanya berfungsi baik sebagai alat musik, maupun sebagai obyek ritual keagamaan. Nekara ini didekorasi oleh pola geometris, berbagai gambaran kisah kehidupan dan perang, hewan dan burung, juga kapal. Hal lainnya yang tidak kalah pentingnya adalah, fungsi nekara sebagai objek tukar atau alat barter dan sebagai benda pusaka bagi masyarakat Dong Son. Pengaruh budaya ini tersebar di berbagai wilayah dari Indonesia bagian timur (Jawa dan Bali) hingga Vietnam dan wilayah Cina Selatan, sehingga lebih dari 200 buah nekara ditemukan walaupun dengan sebutan dan nilai yang berbeda-beda dari masing-masing budaya.

Nekara yang terbuat dari perunggu ini tersebar di wilayah Yunnan kuno, Guizhou, Guangxi, Guangdong, Hainan, Hunan, Chongqing, Sichuan di Cina, Vietnam, Laos, Kamboja, Myanmar, Thailand, Malaysia, Singapura, dan Indonesia. Penemuan pertama dari objek drum ini terdata pada tahun 1976, dan diperkirakan telah ada sejak 2700 tahun yang lalu di Wangjiaba di Yunnan Chuxiong Yi Autonomous Prefecture Cina. Drum tersebut dikategorikan sebagai drum atau nekara Yue terbesar dan terberat bersama dengan Dong Son drum, dan Dian drum.

Penemuan nekara di wilayah New Guinea membuktikan adanya pertukaran budaya sejak ribuan tahun yang lalu, khususnya dari wilayah tersebut hingga masyarakat wilayah Jawa dan Cina. Pada tahun 1902, 165 buah koleksi nekara yang terbuat dari perunggu dipublikasikan oleh F. Heger, ia membagi kategori nekara tersebut menjadi empat tipe. Gambar 4 menunjukkan wilayah persebaran berbagai tipe Dong Son drums. 


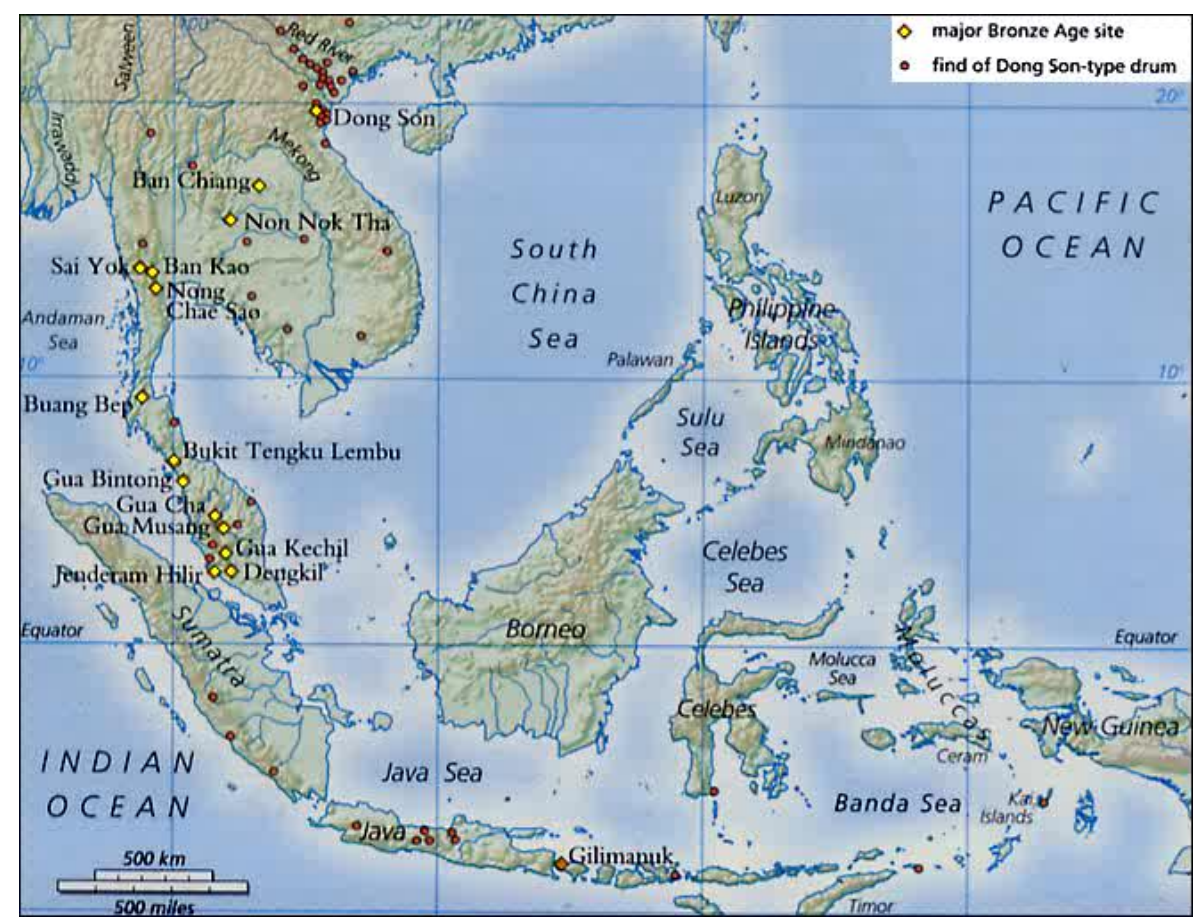

Gambar 4 Wilayah penemuan berbagai tipe Dong Son drums

Nekara-nekara yang ditemukan umumnya memiliki wujud atau bentuk yang mirip dan terbagi simetris menjadi 3 bagian, yaitu bagian tabung (barrel)-atas, bagian tubuh-tengah, dan bagian kakibawah. Pola yang ada pada nekara digambarkan dengan gaya realistik dan menggambarkan bentuk tiruan rumah, orang menari, orang yang sedang menumbuk padi, memukul gendang dan juga orang yang sedang berlayar, bersama dengan gambar binatang dan burung. Setiap kisah memberikan gambaran kehidupan masyarakat Vietnam pada masa lalu. setiap kisah tersebut juga membuktikan bakat dan kreativitas yang tinggi dari masyarakatnya. Gambar berikut adalah contoh pola nekara.

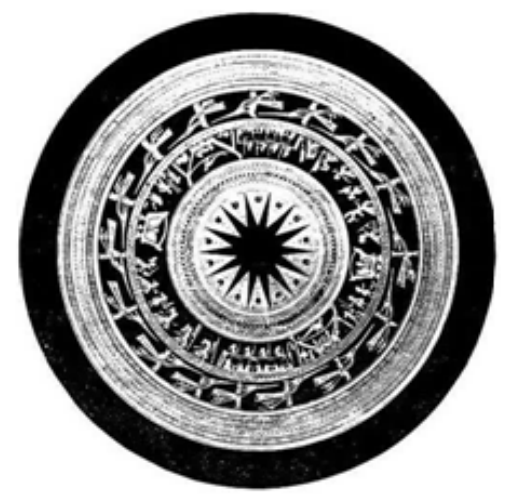

Gambar 5 Pola pada nekara Co Loa

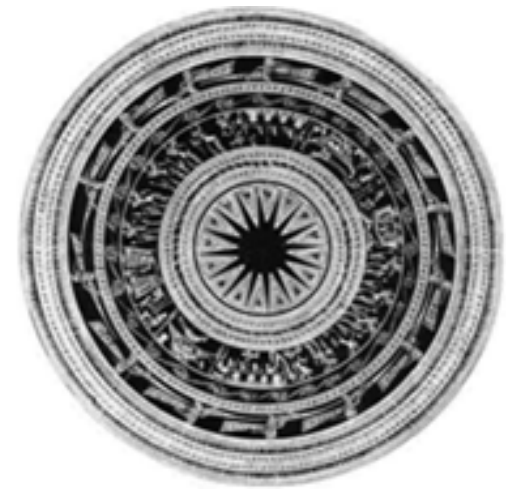

Gambar 6 Pola pada nekara Hoang Ha

Selain beberapa fungsi yang sempat disinggung sebelumnya, para peneliti juga menemukan beberapa fungsi khusus dari nekara. Fungsi nekara tersebut berbeda-beda terkait dengan situasi dan latar belakang dari masing-masing wilayah atau negara. Umumnya nekara digunakan sebagai alat musik di dalam upacara atau festival yang bersifat sakral, misalnya dalam upacara pemanggil hujan, untuk perayaan atau upacara panen, untuk mendukung upacara pernikahan dan upacara pemakaman, 
juga digunakan sebagai sarana bunyi-bunyian untuk memberi perintah kepada pasukan perang. Selain sebagai alat musik, nekara juga digunakan sebagai obyek untuk pemakaman atau sebagai mausoleum, dan juga sebagai lambang kekuatan bagi kepala suku atau pemimpinnya.

Di wilayah Indonesia, nekara yang mendapat pengaruh dari kebudayaan Dong Son disebut sebagai nekara hujan, karena fungsinya memang lebih diutamakan sebagai alat musik khusus untuk upacara memanggil hujan. Motif-motif yang dijumpai pada nekara tersebut banyak menampilkan dukun atau syaman yang terkadang menyamar sebagai binatang bertanduk. Motif-motif tersebut menunjukkan adanya pengaruh Cina, atau lebih jauh lagi mendapat pengaruh masyarakat kawasan stepa. Apabila bentuk ini melambangkan perburuan, maka ada juga motif atau pola khusus yang menunjukkan kegiatan pertanian, yaitu pola bergambar matahari dan katak yang merupakan perlambangan dari air. Nekara sendiri juga sering dikaitkan dengan siklus pertanian. Di dalam upacara memanggil hujan, nekara dipercaya memiliki pengaruh gaib, sehingga ketika ditabuh dapat menimbulkan bunyi petir yang berkaitan dengan datangnya hujan.

Sedangkan untuk beberapa motif nekara yang biasa digunakan untuk upacara pemakaman, dapat terlihat motif yang digunakan berbeda dengan motif nekara yang biasa digunakan untuk upacara pemanggil hujan. Pada nekara yang digunakan untuk upacara pemakaman, motif yang digunakan adalah motif perahu yang dipenuhi oleh orang yang berpakaian dan bertutup kepala dari bulu burung. Motif tersebut diperkirakan menggambarkan arwah orang yang sudah mati sedang berlayar menuju surga yang terletak di suatu tempat di kaki langit sebelah timur lautan luas. Pada masa lalu, jiwa sering digambarkan dengan burung. Hal tersebut mungkin masih berlanjut hingga sekarang oleh kaum syaman.

Selain nekara, banyaknya perlengkapan yang digunakan untuk upacara menunjukkan pentingnya ritual pemakaman bagi masyarakat Dong Son. Mulanya, untuk upacara pemakaman, jenazah dikelilingi oleh semua benda sehari-hari miliknya karena dipercaya arwah tersebut nantinya dapat hidup dengan normal di alam baka setelah kematiannya. Namun, hal ini memakan biaya yang cukup besar. Maka, sebagai upaya penghematan, akhirnya benda-benda yang dikuburkan hanyalah benda-benda yang berukuran kecil saja. Seiring dengan perkembangannya, pada masa akhir kebudayaan Dong Son, muncul bentuk ritual baru. Apabila sebelumnya makam berbentuk peti mati sederhana dari kayu yang kemudian dikubur, maka pada periode berikutnya yang disebut sebagai periode Lach-truong (abad pertama sebelum Masehi) ditemukan makam dari batu bata yang berbentuk terowongan atau lebih tepatnya gua yang terbagi menjadi tiga kamar oleh tembok-tembok lengkung beratap. Meskipun mulanya semua perlengkapan ini dikaitkan dengan pengaruh Yunani mengenai kehidupan alam baka, bisa disimpulkan pula bahwa pengaruh Cina lebih mendominasi sistem kepercayaan yang ada karena mereka beranggapan bahwa arwah orang yang sudah meninggal bersembunyi di dalam gua-gua yang terdapat pada lereng gunung suci, yaitu tempat bersemayamnya arwah yang abadi. Oleh karena itu, makam yang berbentuk terowongan tersebut boleh dikatakan merupakan tiruan dari gua alam gaib. Peti mati atau mausoleum diletakkan di kamar tengah, kemudian di ruangan bersebelahan ditumpuk sesajen sebagai makanan untuk arwah dan pada ruangan ketiga disediakan altar yang terdapat lampu-lampu yang dibawa atau dijaga oleh patung-patung terbuat dari perunggu. Secara sekilas, terasa pengaruh Hellenisme yang merupakan pengaruh kebudayaan Yunani yang menandai akhir kebudayaan Dong Son.

\section{SIMPULAN}

Berdasarkan dari penjelasan yang telah dikemukakan, maka dapat disimpulkan bahwa perkembangan kebudayaan Dong Son telah memberi pengaruh yang cukup besar di berbagai wilayah yang ada di Asia. Pengaruh Dong Son khususnya pada teknik pengolahan perunggu memberi 
pengaruh penting pada perkembangan peradaban manusia pada masa lalu. Nekara sebagai salah satu peninggalan penting dari zaman perunggu merupakan bukti nyata dari kreativitas dan pengembangan pola pikir manusia pada era tersebut.

Dari pembahasan tersebut, dapat disimpulkan bahwa perkembangan manusia pada zaman perunggu telah berkembang dengan pesat. Masyarakat kebudayaan Dong Son khususnya telah mampu mengolah perunggu sebagai material khusus yang lebih kuat dari material batu yang berkembang di era sebelumnya, zaman batu. Salah satu peninggalan khas dari zaman tersebut adalah nekara. Nekara dibuat untuk mendukung kehidupan spiritual dan kepercayaan masyarakat, baik dari segi ritual kepercayaan maupun dari tradisi yang telah diwariskan oleh leluhur mereka. Selain itu, nekara juga memiliki fungsi dan bentuk yang berbeda di setiap wilayah berkembangnya. Berbagai fungsi nekara mencerminkan pola kehidupan masyarakat pada zamannya. Nekara dapat berfungsi sebagai alat musik untuk upacara-upacara khusus, misalnya upacara pemakaman, pernikahan, juga upacara pemanggil hujan untuk mendukung siklus pertanian. Oleh karena itu, akan sangat menarik bila hal ini dapat dipelajari lebih mendalam untuk melihat seberapa jauh perkembangan manusia di zaman perunggu, sehingga dapat dijadikan acuan bagi kita yang hidup saat ini untuk lebih memahami kebudayaan dan sudut pandang yang berbeda. Selain itu, diharapkan bahwa penulisan ini menjadi pemicu bagi kita untuk lebih memahami budaya, sejarah, dan latar belakang kita masing-masing sehingga kita dapat lebih menghargai apa yang telah diwariskan oleh leluhur kita.

\section{DAFTAR PUSTAKA}

Honour, H., \& Fleming, J. (2009). A World History of Art. London: Laurence King. 